\title{
13. \\ DANI PRED SMRT \\ U DRAMI TERASA JOVANA HRISTIĆA \\ I ROMANU PROLJEĆA IVANA GALEBA \\ VLADANA DESNICE
}

\section{Aleksandra Obradović}

UDK: 821.163.42-311.1Desnica, V.:821.163.41-21Hristić, J.

Stručni članak

Sažetak: Rad donosi komparativnu analizu nekih segmenata romana Proljeća Ivana Galeba Vladana Desnice i drame Terasa Jovana Hristića. Polazno tumačenje svoju osnovu pronalazi u dominatnom motivu smrti koji je razvijen u oba književna djela. Pogled na razvoj motiva sužavamo ka analizi dana pred smrt, odnosno predsmrtnog perioda nekoliko Desničinih junaka iz poznatog romana - Ivana Galeba, čovjeka samoubice i čovjeka iz poglavlja o delti - i jedne Hristićeve junakinje čija je smrt izvjesna. Konkretan prostor romaneskne i dramske radnje u vidu terase, balkona i bolnice tumači se kao prelazan u odnosu na graničnu poziciju junaka između života i smrti. Pozitivno semantizovanje ništavila pred Galebovu operaciju i Olgina potreba za Bogom, na kraju Hristićeve drame, markiraju se kao razlike u razvijanju motiva, dok se preplavljenost suncem nakon ozdravljenja i svijest da treba samo umrijeti markiraju kao dva tipa olakšanja nakon drame egzistencije.

Ključne riječi: Vladan Desnica, Jovan Hristić, kontemplacija, prelaz, pomirenost, smrt

Unapred misliti o smrti znači unapred misliti o slobodi. Mišel de Montenj

okušavajući da pronađemo nova značenja i drugačija razumijevanja ljudskog kraja u književnosti, stavljamo u istu ravan dva krajnje različita književna ostvarenja. Njihova žanrovska i poetička različitost ukazuju na različite puteve kojima se dolazi do odgovora na isto pitanje, u čemu ćemo pokušati pronaći suštinsku srodnost prilikom bavljenja vječnim pitanjem postavljenim pred čovjeka. U tom smislu ćemo vidjeti razliku između Desnice i Hristića na planu (ne)prepuštenosti književnih junaka, ali i njihovu sličnost u dostizanju olakšanja neophodnog da bi drama egzistencije dobila svoj epilog.

Prisustvo smrti koja se neprestano naslućuje, nagovještava i otvoreno očekuje jeste ono što najviše spaja ovaj Desničin roman o violinisti koji leži u bolnici kontemplirajući o proljećima i smrti i Hristićevu dramu u kojoj je dramska napetost koncentrisana oko bolesti mlade žene čiji je kraj izvjestan od početka, i čija neizlječiva bolest zaokuplja ostale juna- 
ke. Budući da same fabule ne ostvaruju mnogo analogija, istraživačku pažnju potrebno je usmjeriti na razvoj zajedničkog im motiva smrti i njegove implikacije u djelima. Pri tome se misli na veze između pojedinačnih detalja, koje otvaraju mogućnosti komparativnog tumačenja i postavljanja obojice autora u širi kontekst. Na početku, potrebno je uočiti da oba ova djela, iako pripadaju različitim književnim rodovima, zanemaruju radnju u pravom smislu te riječi. Ona zanemaruju onu aktivnost književnih junaka koja nam pomaže pri oštrom ocrtavanju fabule. Umjesto akcije imamo, dakle, posla sa kontemplacijom. Umjesto kretanja prisutno je mirovanje. Galeb je upućen na bolnicu u kojoj se nalazi, i na sjećanja o kojima govori, ali ne i na neki konkretan pokret, na akciju. Hristićevi junaci, slično tome, svoje vrijeme provode na terasi, u razgovoru ili u mnogoznačnoj tišini. Mogli bismo postaviti pitanje da li upravo blizina smrti utiče na takvu koncepciju i da li u danima do nje mora izostajati konkretno kretanje kako bi se smrt odložila ili kako bi se vrijeme usporilo. Kraj Hristićeve drame biva ispunjen naglim pokretima svih junaka - odlascima sa terase nakon važnih odluka. Poređenje pomenutog sa sudbinama Desničinih junaka do kraja će nam pomoći da provjerimo izrečenu pretpostavku. Mjesto njihovog boravka, bolnicu i terasu, označićemo kao prelazne prostore na kojima su se književni likovi zaustavili kako bi sagledali pređeni put, ali i kako bi potencijalno nastavili dalje. Sadržajni obrisi dana pred smrt upućuju na različite rukavce njihove zaokupljenosti koja se pred neminovnošću gotovo identično sužava u jedno korito. U oba slučaja nastupa olakšanje, a ono se može tumačiti na nekoliko načina.

U poredbenoj situaciji koju postavljamo između Desnice i Hristića imamo posla sa prirodnom smrću posredstvom bolesti. Motiv bolesti uključuje ljekare i medicinu kao činioce njenog mogućeg odlaganja, ali ne i sprječavanja, kao što se to na jednom mjestu u drami i kazuje. Na početku drame zatičemo doktora Ivana koji prvim uzvikom sugeriše suvišnost svakog objašnjavanja pred neminovnošću koja slijedi, a koja će dramsku radnju pritiskati do njenog kraja: „Šta da kažem?" njava prostor između Hristićevih junaka. Doktor koji priznaje da nema načina da se spase, a kao prijatelj bolesne žene ne može da joj ispriča ,jednu od onih lekarskih priča “2 sam predstavlja svoju profesiju kao pokušaj odlaganja smrti koji hoće da bude njeno sprječavanje. Istu svijest sa druge strane, iz perspektive pacijenta, izražava Ivan Galeb kojem doktor kaže da će im svirati kad ozdravi, što on, iako neočekivano ganut, racionalno komentariše: „Bolesnik voli i takav površan optimizam. “3 Desnica ipak ostavlja prostora za sunčan dan koji će medicina Galebu donijeti, nasuprot Hristiću, koji suočavanje ljekara s neizlječivom bolešću predstavlja kao izliv apsolutnog obesmišljenja čitave profesije. Hristićev Ivan od bolesti pravi doktorsku disertaciju, i u tome prepoznaje samo zanat i ništa drugo, jer ništa više nije sposoban da uradi, a prema njegovom ljudskom osjećanju morao bi. Ovakvi prvobitni stavovi prema mogućnostima ozdravljenja pokazuju čitaocu izvjesnost Olgine smrti i neizvjesnost Galebove. U Olginom odnosu prema bolesti nema prostora ni za neočekivanu ganutost, koja bi bila trenutno zavaravanje da je sve u redu, kao što joj je pri izlasku iz bolnice rečeno.

Jovan Hristić, Terasa, Beograd 2004., 9.

Isto.

Vladan Desnica, Proljeća Ivana Galeba, Beograd 1981., 59. 
Doktorove pretpostavke o ljudima koji svijest o skorašnjoj smrti projektuju u samoubistvo realizovane su u priči koju je Desnica inkorporirao u svoj roman. Junak te priče medicini nije pružio priliku. Riječ je o pripovjeci poznatoj pod nazivom Balkon, a koja tematizuje čovjekov strah od smrti pod samoiniciranom pretpostavkom da ima rak. Provodeći svoje dane pred smrt na balkonu jedne zgrade, posmatrajući odatle svijet od kojeg se udaljava, neimenovani čovjek implicitno izražava skepsu prema medicinskoj pomoći - nije joj povjerio ni običnu provjeru simptoma koje osjeća, a obdukcija nakon smrti pokazuje da on rak nije ni imao. Narator taj podatak smatra nevažnim za samu priču, kao neki post scriptum koji se tek onako nadodaje priči. U tome, $s$ jedne strane, čitamo neminovnost smrti koja se u datom času dogodi bez obzira na konkretne okolnosti, a sa druge strane, taj post scriptum biva ono najvažnije što je autor imao da kaže. Čovjekova potreba „da ipak nekako obilježi, da ipak nečim podvuče svoju smrt; da ona ne bude baš sasvim neznatna, sasvim nezapažena “4 objašnjava suvišnost činjenice da on nije ni bio bolestan, odnosno - njemu je bilo potrebno „da ipak saljude zainteresira, kointeresira, za se i za nju“.

Upotreba ovih riječi sa saučesničkim značenjem naglašava ljudski strah od smrti u kojoj se biva sam. Ovaj junak upravo zato skače na ulicu, među prolaznike. I Olga iz Hristićeve drame zato želi da se vrati u bolnicu iako je puštena kući: kod kuće osjeća jaz koji njena bolest pravi između nje i njenog muža. U istom kontekstu Olga ne pronalazi način da zauzme svoje mjesto u njihovoj kući, u haosu koji bez nje funkcioniše; ona ne želi ni da siđe do plaže, da započne bilo šta, suočena sa sviješću o svom neizvjesnom trajanju. Ona se od početka pribiližava iracionalnom svijetu Blankine umrle porodice - što na nivou sličnosti sa njenom preminulom kćerkom i osjećanjem pripadnosti u toj nepoznatoj kući u kojoj nema pravog života, što insistiranjem na upotrebi predmeta preminulih, i do kraja svjesnim prepuštanjem muža mladoj djevojci u postupku poklanjanja haljine, o čemu će još biti riječi. Olgin prezir prema životu, kakav joj je do kraja preostao, van konteksta ljudskog straha od smrti biva ono zbog čega je njeno ljetovanje postalo samo ćutanje na terasi. Još je Montenj pisao o osjećanju života pri svijesti o skorašnjoj smrti:

Ako je smrt brza i nasilna, nemamo vremena da od nje strahujemo; ako nije takva, primećujem da što dublje ulazim u bolest, to prirodnije počinjem da osećam izvestan prezir prema životu. ${ }^{6}$

Zanimljivo je da samoubica bira balkon kao mjesto svoje fantazije o smrti. Privremena utjeha koju je na tom mjestu sticao poticala je od male krpice vedrine koja je naslućivala lijepo vrijeme i „nešto neodređeno obećavala“.7 Istovremeno, to je i mjesto njegovog posljednjeg koraka, koraka kojim je skočio u smrt. Hristićevi junaci dolaze na ljetovanje iznajmivši kuću izvjesne Blanke - posljednjeg živog ukućanina, što implicira svojevrstan prostor umrlih - kako bi pobjegli od Olgine smrti, ili kako bi se $s$ njome suočili. Terasa te kuće biva mjesto na kojem provode najviše vremena, i predstavljena je kao prostor nji-

4 Isto, 108. Videti i: Vladan Desnica, „Balkon“, Pripovijetke (= Sabrana djela Vladana Desnice, knj. 3), Zagreb 1974., 341-343.

5 V. Desnica, Proljeća Ivana Galeba, 108.

6 Mišel de Montenj, Ogledi, Beograd 1967., 35.

7 V. Desnica, Proljeća Ivana Galeba, 108. 
hove kontemplacije, prostor tišine i slutnje, jer se sa terase mora nekuda krenuti. I terasa i balkon su ovdje simboli prostora odluke i suočavanja sa situacijom kakva jeste. Potreba za izmještanjem prisutna je i kod Desnice i kod Hristića. Izmještanje je moguće vidjeti kao bježanje i kao vid pokušaja introspekcije. S jedne strane, primjećeno je da se Desničini junaci ne kreću ka nečemu, nego gotovo uvijek od nečega, što „znači da kretanje u sebi sadrži komponentu bežanja“ “, 8 dok, sa druge, imamo neprestano suočavanje: „Probdio sam duge noći, sred bijele mistike bolnice, u kontemplaciji smrti. Licem u lice s njom. ${ }^{\text {“9 }}$ Takve dve perspektive ogoljene su i u sljedećem Olginom iskazu:

Negde sam pročitala: „Sama sam i siromašna sam, jer mi ne treba ni ono što imam.“ To je rekao neko ko se već oprostio, ko je već na drugoj strani... Izgledalo mi je strašno, zato što sam videla samo ovu stranu, našu stranu. Ona je strašna. To je zato što sam gledala sa pogrešne strane, a treba samo sve preokrenuti. Kao da izlazim iz kuće, i sobu u kojoj sam živela gledam spolja, sa ulice. Postane drukčija, i odjednom shvatim da u onome zašta sam mislila da je nered postoji neki red... Htela sam da uredim, ali sad vidim da ne treba ništa uređivati. Treba samo izaći. Jednostavno se okrenuti i izaći. ${ }^{10}$

Konkretan arhitektonski izgled terase / balkona upućuje na prostor koji se nastavlja na unutrašnji ali stremi ka spoljašnjosti koja se ne može potpuno doseći. U tome kontekstu se usuđujemo da ga tumačimo kao prelazni prostor između dva stanja. Na to se nadovezuje i bolnica u kojoj Galeb boravi u procesu ozdravljenja. Sva tri mjesta bivaju prostori kontemplacije i razmišljanja o smrti, između ostalog. U tome kontekstu dani pred smrt u ovim djelima prepoznaju se kao postupni polazak iz života i navikavanje na misao o sopstvenom kraju. Analogno tome, govoreći o smrti Montenj na jednom mjestu navodi kao prvu stavku:

Da bismo tom dušmaninu oduzeli najveću prednost nad nama, postupimo obratno od onog što većina čini. Oduzmimo mu neobičnost, opštimo sa njim, navikavajmo se na njega, i najčešće od svega mislimo na smrt. ${ }^{11}$

Ako je to ono što čine i Desničini i Hristićevi junaci, pa i pisci pišući o tome, onda njihova djela moramo razumjeti kao borbu protiv iste te smrti, ali ne u kontekstu vječnog života posredstvom književnosti, već u smislu navikavanja na nestajanje kao takvo. Budući da ono što nam je blisko doživljavamo kao obično i poznato, smrt bi mogla, ako je učinimo običnom, postati upravo bliža, a čovjek u toj bliskosti, kao u svakoj drugoj, slobodniji. U razrađivanju te misli Montenj i zaključuje da „unapred misliti o smrti znači unapred misliti o slobodi“" 12 što, navedeno kao moto ovoga teksta, upućuje upravo na krajnju otvorenost i potencijalnu smirenost koju dani pred smrt u ovim djelima nude, paradoksalno, sa strahom i neprihvatanjem u svijesti o smrti koja je predstavljena iz perspektive Ivana Galeba kao dječaka ili doktora Ivana i Vladana u Terasi.

\footnotetext{
8 Slobodan Vladušić, „Desnica i postmoderni plutajući subjekt“, Godišnjak Filozofskog fakulteta u Novom Sadu, 41/2016., br. 1, 507.

9 V. Desnica, Proljeća Ivana Galeba, 97.

10 J. Hristić, Terasa, 45.

11 M. Montenj, Ogledi, 30.

12 Isto.
} 
Naime, mladi Ivan Galeb u svom djetinjstvu, u pregršti besmrtnosti, smatrao je da je smrt samo za druge, da „ona pripada ne- $j a^{\text {“ }},{ }^{13}$ jer je dijete svjesno samo onoga čemu je mjerilo njegovo sopstveno postojanje. „Iz svesti o jedinstvenosti i nenadoknadivosti svoga 'ja' izrasta stalna intenzivna zaokupljenost Desničinog junaka problemima nestajanja“, reći će Nikola Milošević. ${ }^{14} \mathrm{Da}$ i odrasli ljudi žive u zabludi da se smrt i bolest dešavaju samo drugima, primjer nam je Hristićev Vladan, koji odbija da registruje podsvjesno saznanje da će mu žena, Olga, umrijeti. On se brani jednom vrstom razonode od onoga što je neminovno: odlazi na kupanje, da roni, u lov. Zarad bježanja od smrti Vladan se okreće Veri i novoj, nabujaloj životnoj struji kojom njen lik odiše. Nasuprot Olgi, koja pravi svečanu večeru koristeći posuđe preminulih ukućana, i koja skuplja rasute dijelove Ivanove disertacije koju u stvari čini njena bolest, Vera djeluje kao jedini lik u drami koji nema dodira sa smrću. I ona do kraja ostaje takva, ne prihvatajući ni haljinu koju joj Olga poklanja - kao simbol onog života koji više nije njen. Gledajući u Veri sve ono što je u njoj bolest pregazila, osjećajući se starom i sebi stranom u ogledalu, Olga joj poklanja haljinu koju je to veče prvi put obukla, i shvatila da u njoj nema više onoga što bi haljinu mladosti moglo da nosi. Saznajući za njihov zajednički odlazak, Olga na taj simbolički način prihvata njegov izbor da pobjegne od nje koja nestaje i da počne nešto iz početka.

Vladan dolazi iz njihove sobe pod svježim utiskom Olginog buncanja u snu: „Hteo sam da pružim ruku, da je umirim. Ali to je odjednom za mene bila druga žena, žena koju ne poznajem. ${ }^{\text {"15 }}$ Ovaj iskaz podsjeća na motiv koji Desnica razvija u Proljećima, a vezan je za lica spavajućih, i Galebovo zaziranje od njih. Galeb priznaje, na više mjesta, da je to uvijek u njemu rađalo „neki panični provalijski nesrazmjer“ te, analogno Vladanovom zaziranju od žene, zaključuje da „između usnulog i budnog supružnika (...) legne udaljenost od čitavih eona, od čitavih geoloških doba" ${ }^{16}$ udaljenost koja između bolesnog i zdravog supružnika postaje još veća. U ovakvom poređenju sa Galebovom panikom od lica spavajućih otkriva se da Vladan svoju ženu ne poznaje, zato što se na njenom licu usnule, i u njenom buncanju, ogleda sva istina o njenoj bolesti i smrti, istina od koje je on pokušavao pobjeći. Galebova analogija između lica umrlih i lica spavajućih, koja bi, kao i ova prva, trebalo prekriti maramom, otvara upravo pitanje straha od smrti i svega što je nalik na nju. Otuda Olga ne prepoznaje samu sebe u ogledalu, plašeći se suočavanja sa nestajanjem, kao što Vladan ne prepoznajući je dok spava, nju onu koja je bila, okreće nov list, list života koji obećava nešto više nego što su predsmrtni dani i unapred izgubljena bitka. Taj život je Vera i Pariz, ali prvo odlazak sa terase, koji djeluje kao prelomni trenutak i za njega i za Ivana, koji nedugo za njim takođe izlazi sa svojim stvarima, i odlazi.

Značajan dio Terase, važan za ovu temu, jeste Olgin monolog na kraju drame. Ta žena koja je smrtno bolesna, iako je jedno od značenja njenog imena upravo paradoksalno zdrava, „kao da polako nestaje tokom drame, kao da je već postala sena“. ${ }^{17}$ Ona ne dobija

13 V. Desnica, Proljeća Ivana Galeba, 74.

14 Nikola Milošević, „Duh modernog vremena u Proljećima Ivana Galeba“, Zidanica na pesku, Beograd 1978., 63.

15 J. Hristić, Terasa, 26.

16 V. Desnica, Proljéća Ivana Galeba, 60.

17 Vesna D. Crepuljarević, „Čin peti: Terasa“, Zbornik Matice srpske za scenske umetnosti i muziku, 49/2013., 157. 
odgovor na molbu upućenu Ivanu da ostane još malo, niti odgovor na posljednja pitanja koja se odnose na izbrojani ostatak života. Didaskalije navode kako „Olga načini nekoliko koraka po terasi, onda odjednom krikne, kao životinja izbezumljena od straha“ ${ }^{18}$ pokušavajući da potvrdi da je još tu, iako uplašena i sama, ali još prisutna. Taj krik proizvodi saznanje da su njeni dani, nakon odlaska dvojice najbližih ljudi, postali samo dani pred smrt.

U petoj slici ona je i dalje sama na terasi, ali vidno pribranija. Pokušavajući da skupi ono malo egzistencije što joj je ostalo, i svijesti o sebi, ona se otvara tek tu, na kraju. Slično Galebu, koji je sam i zahvalan što je sam jer zna kako je mučno posjećivanje samrtnika, Olga konstatuje da je bolje što su svi otišli. Obraća se zamišljenom Ivanu iskazujući da zna sve što je tonulo u njihovo ćutanje:

Sećaš li se kako sam otišla iz bolnice? (...) Bilo mi je važno da izađem, da što pre dođem kući. I tek kad si otišao, meni je palo na pamet da me tog dana nijednom nisi pogledao u oči. Stalno si gledao nekud pored mene, kao da više ne postojim. (...) Kada sam se iz bolnice vratila kući, sve je bilo onako kao što sam mislila da će biti, u spavaćoj sobi nenamešten krevet, u Vladanovoj nered, u kuhinji gomila prljavih tanjira i praznih flaša. Taj nered mi se odjednom učinio kao neki red, koji se napravio bez mene. Kao da više nisam potrebna, kao da više i ne postojim. (...) Ali ti samo ćutiš, Vladan stalno odlazi nekuda, kad se vrati i on ćuti. I ja propadam u to vaše ćutanje kao u provaliju. ${ }^{19}$

U njenim riječima čitamo jasan nesrazmjer između čovjeka kojem je predodređeno skoro nestajanje i onih koji to nestajanje prate nastavljajući svoje živote. Tim njihovim nastavljanjem života, u kojem ona gubi svoje mjesto, Olga tone u nepostojanje dublje nego posredstvom bolesti. Na sličan način Galeb govori iz perspektive samrtnika, konstatujući neiskupivu samoću u smrti:

U takvim časovima i najbliži nam postaju tuđi. Pored nas su - a opet tako daleki. (...) Tako bismo trebali nečiju prisnu blizinu, a tako smo neiskupivo sami! Između njih i nas raspukla je jedna granica, jedan uski no nepremostivi jaz: spadamo u dvije različite vrste, u dva različita svijeta: oni u svijet živih, mi u svijet umirućih. A nema te razlike koja ljude razdvaja tako duboko kao ta. (...) I eto, u krajnjem času, kad nam najviše treba nečija prisna blizina, između nas i naših najbližih, između nas i svega, zaleglo je nešto podmuklo, zalegla je jedna neprelazna tuđost, tuđost laži. I tu nema pomoći. Vidimo ih gdje se pate, a ne možemo da osjetimo njihovu toplinu. Traže riječ u koju bi legla sva prisnost, sva duša, ali takva riječ ne postoji. Skrivaju nam istinu, iz samilosti. Skrivaju nam samilost, iz obzira. (...) Između nas i njih leži nešto premučano, nešto tamno, kao umotan leš..$^{20}$

Njihovo poimanje ono malo preostalog života biva suženo u doživljaj postojanja koje je već sada, dok smrt još nije nastupila, upitno. Olga to vidi u Ivanovom skretanju pogleda i rasporedu zajedničkih stvari u kući u kojoj je živjela sa Vladanom, dok Galeb tu sumnju konstatuje budući u postoperativnom stanju: „U potpunoj tišini, na mahove posumnjam da li uopće postojim.“21 Svjesna da „mora da se sredi, da mora nešto da uradi“", kako govori u svom monologu, Olga više ne pronalazi nikakav smisao i počinje da se pita, eksplicirajući potrebu za jednim iracionalnim osloncem:

\footnotetext{
18 J. Hristić, Terasa, 50.

19 Isto, 51-52.

20 V. Desnica, Proljeća Ivana Galeba, 335.

21 Isto, 341.
} 
Ne znam da li ti postojiš ili ne postojiš, ali ne bi smeo da nas ostaviš. Mora postojati neko ko će nam pomoći. Mora postojati neko ko će biti jači od nas i moćniji od nas. Mi smo suviše slabi i suviše nemoćni da bismo na svetu mogli postojati samo mi, i niko više. Počni da postojiš. Počni da postojišn $!^{22}$

Njeno obraćanje Bogu na kraju djeluje kao očajnički pokušaj borbe sa samoćom pred smrt koja je čeka. Kao zamišljeni odgovor ili konkretizovano ćutanje Hristić u dijaloškom rasporedu navodi vjetar i more. Olgine uzvike zamjenjuje smijeh i potom smirena konstatacija: „I šta onda? To je sve! Treba samo..." ${ }^{23}$ Stiče se utisak da zamišljenim odgovorima dobija potrebno olakšanje. Ona takođe odlazi sa terase, kao prelaznog prostora, ali, za razliku od Ivana i Vladana, Olga ne odlazi sa svojim, ili bilo kakvim stvarima, već zbacuje sa sebe sve, sluteći da joj tamo kuda ide ništa ne treba.

Njen odlazak u nagosti, zbacivanjem ogrtača, može predstavljati simboličku smrt, odlazak iz života doveden u analošku vezu sa dolaskom u život, sa rođenjem. Osim toga, ovakav njen gest asocira nas na Desničinog junaka koji kreće svim putevima delte, oslobađajući se svega što je do tada činilo njegov identitet, uključujući i odjeću. I Hristić i Desnica na ovom mjestu iskazuju potrebu svojih junaka da odahnu od misterije smrti i dosegnu lakoću kojom pobjeđuju ovozemaljske granice. Desničin narator smišlja priču kojom pokušava riješiti enigmu nestanka jednog bezimenog, po svemu neodređenog čovjeka. Njegova rekonstrukcija događaja ide u pravcu odlaska putem koji vodi uvijek napred, a ne dovodi nikamo, u pravcu kretanja deltom mogućnosti koja je rješenje problema izbora, jer predstavlja izbor svega. Obrnuto proporcionalna, Olgina situacija, u kojoj je pravi problem nemanje izbora, kao razrješenje sluti jedino apsolutnu rezignaciju. No ne čini se da je Hristić kraj svoje drame označio tako. Hristićeva junakinja se od Desničinih junaka razlikuje po težnji ka iracionalnom, duhovnom osloncu koji joj može dati nadu da terasa sa koje odlazi nije posljednje što će vidjeti, i da za dostizanje mira iz kakvog je rođenjem došla, treba samo - umrijeti. Čovjek koji polazi deltom mogućnosti čezne samo da se ne probudi, jer bi život značio izbor, i njegovu težinu. Otuda i on i Olga bivaju simbolički laki u nestajanju.

Imajući u vidu da Desničin čovjek samoubica, kao i čovjek iz delte, te sam Ivan Galeb teže ka jednom vidu ništavila koje njihovom biću, nespremnom za akciju i izbor, najbolje odgovara, primjećuje se da predsmrtni dani u njihovom slučaju djeluju kao pokušaj olakšanja od tjeskobe egzistencije. Gradeći potpuno drugačije aktere sa sličnom nespremnošću u stvarnim životnim okolnostima, Hristić u svojoj drami junakinju dovodi do potrebe za Bogom kao osloncem, a onda do simboličnog povratka u prenatalno. Galebovo ozdravljenje sugeriše Desničin optimizam uprkos kontemplacijama o ništavilu, dok Olgina nagost pomireno kreće ništavilu u susret, u ubjeđenju da će tamo nešto početi da postoji. Prihvatanje da se umre donosi mir, i odlazak sa terase i iz bolnice implicira kraj predsmrtnih dana, jer smrt je, pomirenošću s njom samom, pobijeđena. Pomirenost je sloboda koju bi čovjek u susretu sa svojom smrtnosti morao sebi priuštiti.

22 J. Hristić, Terasa, 52-53.

23 Isto, 53. 


\section{$\cos$}

\section{Literatura}

Vesna D. Crepuljarević, „Čin peti: Terasa“, Zbornik Matice srpske za scenske umetnosti i muziku, 49/2013., 153-168.

Vladan Desnica, „Balkon“, Pripovijetke (= Sabrana djela Vladana Desnice, knj. 3), Zagreb 1974., 341-343.

Vladan Desnica, Proljeća Ivana Galeba, Beograd 1981.

Jovan Hristić, Terasa, Beograd 2004.

Nikola MilošEvić, „Duh modernog vremena u Proljećima Ivana Galeba“, Zidanica na pesku. Književnost i metafizika, Beograd 1978., 59-77.

Mišel de MontenJ, Ogledi, Beograd 1967.

Slobodan Vladušıć, „Desnica i postmoderni plutajući subjekt“, Godišnjak Filozofskog fakulteta u Novom Sadu, 41/2016., br. 1, 497-510.

\section{$\cos$}

\section{The Days PRECEDing DEATH IN JOVAN HRISTIĆ'S PLAY Terasa and Vladan Desnica's novel Proljé́a IVANa GALEBA}

The paper contains a comparative analysis of some segments of Vladan Desnica's novel Proljeća Ivana Galeba (The Springs of Ivan Galeb) and Jovan Hristićs play Terasa (The Terrace). The initial interpretation draws on the central motif of death, which is explored in both literary works. While analyzing the motif of death, we focus on the days preceding death, that is, the premortal period of several characters from Desnica's well-known novel: Ivan Galeb, the man who commits suicide and the man from the delta chapter, as well as a woman from Hristićs play whose death is also imminent. Our focus is then expanded in the context of the philosophy reflected in the experience of death, as depicted in these two literary works. The typological analogies with Montaigne's and Pascal's understanding of death are also addressed. The setting of the hospital and the balcony, or the terrace, is interpreted as a transitional space in terms of the characters' position in the space between life and death. The positive connotations ascribed to death before Galeb's surgery and Olga's need for God at the end of Hristić's play are seen as differences in treating the motif, while being flooded by sunlight after recovery and the awareness that dying is the only thing that all one really has to do is die are seen as two types of relief following existential drama. Galeb's recovery after having spent so many endless days teetering on the brink of death is a reflection of Desnica's optimism. Hristić's female protagonist, on the other hand, symbolises a return to the prenatal, a closing of the circle of life, while waiting for God, who must not abandon us, to begin to exist. The drama of existence precedes a reconciliation with the world and with oneself, either in life or in death.

Key words: Vladan Desnica, Jovan Hristić, contemplation, transition, reconciliation, death 